[Supporting information to accompany]

\title{
A Convergent Coordination Chemistry-Based Approach to Dissymmetric Macrocyclic Cofacial Porphyrin Complexes
}

\author{
Christopher G. Oliveri ${ }^{\dagger}$, Jungseok Heo ${ }^{\dagger}$, SonBinh T. Nguyen ${ }^{\dagger *}$, \\ Chad A. Mirkin ${ }^{\dagger}$ and Zdzislaw Wawrzak ${ }^{\ddagger}$. \\ $\dagger$ Department of Chemistry and the International Institute for Nanotechnology, Northwestern \\ University, 2145 Sheridan Road, Evanston, Illinois, 60208-3113, U.S.A. \\ $\$$ Department of Biochemistry, Molecular Biology and Cell Biology, Northwestern University, \\ 2205 Tech Drive, Evanston, Illinois, 60208-3500, U.S.A.
}

General Methods and Instrument Details $S-1$

Synthetic Details

$S-2-S-7$

\section{General Methods and Instrument Details}

All reactions were carried out under an inert atmosphere of dinitrogen using standard Schlenk techniques or an inert atmosphere glovebox unless otherwise noted. Tetrahydrofuran (THF), diethyl ether $\left(\mathrm{Et}_{2} \mathrm{O}\right)$, dichloromethane $\left(\mathrm{CH}_{2} \mathrm{Cl}_{2}\right)$, and hexanes were purified according to published methods. ${ }^{1}$ All solvents were deoxygenated with dinitrogen prior to use. Deuterated solvents (Cambridge Isotope Laboratories Inc.) were obtained from commercial sources and used as received. All other chemicals were used as received from Aldrich Chemical Company. Ligands 3 and $\mathbf{4}$ were prepared according to literature procedures. ${ }^{2}$

${ }^{1} \mathrm{H}$ NMR (300.22 or $400.18 \mathrm{MHz}$ ) spectra were recorded on either a Varian Mercury 300 $\mathrm{MHz}$ or a Varian Mercury $400 \mathrm{MHz}$ FTNMR spectrometer and referenced to relative residual proton resonances. ${ }^{31} \mathrm{P}\left\{{ }^{1} \mathrm{H}\right\} \mathrm{NMR}(121.53$ or $161.95 \mathrm{MHz})$ spectra were recorded on either a Varian Mercury $300 \mathrm{MHz}$ or a Varian Mercury $400 \mathrm{MHz}$ FT-NMR spectrometer and referenced relative to an external $85 \% \mathrm{H}_{3} \mathrm{PO}_{4}$ standard. All chemical shifts are reported in ppm. FTIR spectra were obtained using a ThermoNicolet Nexus 670 FTIR spectrometer and a solution cell with $\mathrm{NaCl}$ windows. Electrospray ionization mass spectra (ESIMS) were recorded on a 
Micromass Quatro II triple quadrapole mass spectrometer. Electron impact mass spectra (EIMS) were recorded on a Fisions VG 70-250 SE mass spectrometer.

\section{[5,15-Bis-\{4-[2-(diphenylphosphinothioyl)ethoxy]phenyl\}-10,20-bis-}

(mesityl)porphyrinato]magnesium ${ }^{\mathrm{II}}$ (1). Under ambient conditions, 5,15-Bis-\{4-[2(diphenylphosphinothioyl)ethoxy]phenyl\}-10,20-bis-(mesityl)porphyrin (402 mg, $0.328 \mathrm{mmol}$ ), $\operatorname{MgBr}_{2}(2.41 \mathrm{~g}, 13.1 \mathrm{mmol})$, and $\mathrm{NEt}_{3}(7.3 \mathrm{~mL}, 52.5 \mathrm{mmol})$ were combined in a $250-\mathrm{mL}$ roundbottom flask and stirred for $4 \mathrm{~h}$ at $\mathrm{rt}$ in $\mathrm{CH}_{2} \mathrm{Cl}_{2}(200 \mathrm{~mL})$. The solution was then washed with $\mathrm{H}_{2} \mathrm{O}(2 \times 100 \mathrm{~mL})$ and extracted with $\mathrm{CH}_{2} \mathrm{Cl}_{2}(100 \mathrm{~mL})$. The organic layer was further washed with $\mathrm{H}_{2} \mathrm{O}(100 \mathrm{~mL})$, dried over $\mathrm{MgSO}_{4}$, and concentrated to give $\mathbf{1}$ as a crude purple microcrystalline solid which was further purified via column chromatography over neutral alumina $\left(\mathrm{CH}_{2} \mathrm{Cl}_{2}\right.$ used to elute unreacted freebase porphyrin followed by THF to elute 1 as a purple band) (378 mg, 93\% yield). ${ }^{1} \mathrm{H}$ NMR $\left(\mathrm{CD}_{2} \mathrm{Cl}_{2}\right): \delta 1.82\left(\mathrm{~s}, 12 \mathrm{H}, \mathrm{CH}_{3}\right), 2.63\left(\mathrm{~m}, 6 \mathrm{H}, \mathrm{CH}_{3}\right)$, $3.16\left(\mathrm{~m}, 4 \mathrm{H}, \mathrm{OCH}_{2} \mathrm{CH}_{2} \mathrm{P}=\mathrm{S}\right), 4.65\left(\mathrm{~m}, 4 \mathrm{H}, \mathrm{OCH}_{2} \mathrm{CH}_{2} \mathrm{P}=\mathrm{S}\right), 7.05\left(\mathrm{~d}, 4 \mathrm{H}, J_{\mathrm{H}-\mathrm{H}}=8.4 \mathrm{~Hz}, \operatorname{Ar} H\right)$, 7.29 (s, 4H, ArH), 7.59 (br s, 10H, ArH), $7.97-8.07$ (m, 14H, $\operatorname{Ar} H$ ), 8.64 (d, 4H, $J_{\mathrm{H}-\mathrm{H}}=4.5 \mathrm{~Hz}$, $\operatorname{Ar} H), 8.78\left(\mathrm{~d}, 4 \mathrm{H}, J_{\mathrm{H}-\mathrm{H}}=4.2 \mathrm{~Hz}, \operatorname{Ar} H\right) .{ }^{31} \mathrm{P}\left\{{ }^{1} \mathrm{H}\right\} \mathrm{NMR}\left(\mathrm{CD}_{2} \mathrm{Cl}_{2}\right): \delta 39.5(\mathrm{~s}) . \quad$ EIMS $(\mathrm{m} / \mathrm{z})$ : Calcd. $1241.7\left[\mathrm{M}^{+}\right]$. Found: 1241.3.

\section{[5,15-Bis-[4-(2-diphenylphosphanylethoxy)phenyl]-10,20-bis-(mesityl)porphyrinato]}

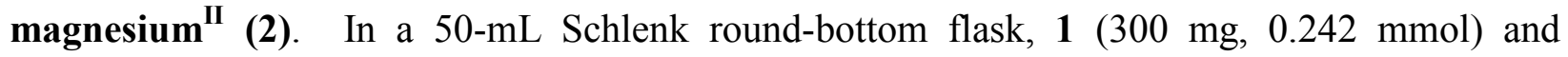
$\mathrm{Cp}_{2} \mathrm{ZrHCl}(406 \mathrm{mg}, 1.57 \mathrm{mmol})$ were stirred in THF $(30 \mathrm{~mL})$ under $\mathrm{N}_{2}$ at $60{ }^{\circ} \mathrm{C}$ for $4 \mathrm{~h}$. The solvent was removed and the reaction was purified via column chromatography (neutral alumina, THF as eluent) in a glove box under an atmosphere of $\mathrm{N}_{2}$. The solvent was removed in vacuo to yield 2 as an air-sensitive purple microcrystalline solid ( $253 \mathrm{mg}, 89 \%$ yield). ${ }^{1} \mathrm{H}$ NMR (THF- $d_{8}$ ): $\delta 1.80\left(\mathrm{~s}, 12 \mathrm{H}, \mathrm{CH}_{3}\right), 2.57\left(\mathrm{~s}, 6 \mathrm{H}, \mathrm{CH}_{3}\right), 2.77\left(\mathrm{~m}, 4 \mathrm{H}, \mathrm{OCH}_{2} \mathrm{CH}_{2} \mathrm{P}\right), 4.37\left(\mathrm{~m}, 4 \mathrm{H}, \mathrm{OCH}_{2} \mathrm{CH}_{2} \mathrm{P}\right)$, $7.12\left(\mathrm{~d}, 4 \mathrm{H}, J_{\mathrm{H}-\mathrm{H}}=8.4 \mathrm{~Hz}, \operatorname{Ar} H\right), 7.24-7.37(\mathrm{bm}, 14 \mathrm{H}, \operatorname{Ar} H), 7.57(\mathrm{bs}, 10 \mathrm{H}), 8.01\left(\mathrm{~d}, 4 \mathrm{H}, J_{\mathrm{H}-\mathrm{H}}=\right.$ $7.6 \mathrm{~Hz}, \operatorname{Ar} H), 8.54\left(\mathrm{~d}, 4 \mathrm{H}, J_{\mathrm{H}-\mathrm{H}}=4.4 \mathrm{~Hz}, \operatorname{Ar} H\right), 8.69\left(\mathrm{~d}, 4 \mathrm{H}, J_{\mathrm{H}-\mathrm{H}}=4.4 \mathrm{~Hz}, \operatorname{Ar} H\right) .{ }^{31} \mathrm{P}\left\{{ }^{1} \mathrm{H}\right\} \mathrm{NMR}$ $\left(\right.$ THF- $\left.d_{8}\right): \delta-21.2(\mathrm{~s})$. EIMS $(\mathrm{m} / \mathrm{z})$ : Calcd. $1153.3\left[\mathrm{M}^{+}-\mathrm{Mg}^{2+}\right]$. Found: 1152.9.

(2)(4) $\mathrm{Rh}_{2} \mathbf{C l}_{\mathbf{2}}$ (Compound 5). Ligand 2 (94.2 $\mathrm{mg}, 0.0789 \mathrm{mmol}$ ), ligand 4 (100 mg, 0.0789 $\mathrm{mmol})$, and $\left[\mathrm{Rh}(\mathrm{COD}) \mathrm{Cl}_{2}(38.9 \mathrm{mg}, 0.0789 \mathrm{mmol})\right.$ were added to a $20-\mathrm{mL}$ vial and dissolved in 
THF (15 mL). This solution was transferred to a $50 \mathrm{~mL}$ Schlenk round-bottom flask and sonicated for $1 \mathrm{~h}$. During the course of the reaction, the solution went from a clear purple solution to a cloudy purple solution, at which point the solvent was removed under vacuum. The purple solid was sonicated in hexanes $(20 \mathrm{~mL})$ for $1 \mathrm{~h}$, filtered, washed with fresh $\mathrm{Et}_{2} \mathrm{O}(2 \times 10$ $\mathrm{mL}$ ) and dried under vacuum to yield 5 as an air-sensitive solid (200 mg, 94\% yield). ${ }^{1} \mathrm{H} \mathrm{NMR}$ $\left(\mathrm{CD}_{2} \mathrm{Cl}_{2}\right.$ ): $\delta 1.62$ (br m, 24H, mesityl), 2.48 (br m, 12H, mesityl), 2.84 (m, 8H, $\mathrm{SCH}_{2} \mathrm{CH}_{2} \mathrm{P}$ and $\mathrm{SCH}_{2} \mathrm{CH}_{2} \mathrm{P}$ ), $3.08\left(\mathrm{~m}, 4 \mathrm{H}, \mathrm{SCH}_{2} \mathrm{CH}_{2} \mathrm{P}\right.$ ), 4.74 (br m, 4H, OCH $\mathrm{CH}_{2} \mathrm{P}$ ), $7.11-8.12$ (br m, 62H, $\operatorname{Ar} H$ ), 8.27 (br d, 8H, ArH), 8.51 (br d, 8H, ArH), 8.87 (d, 2H, $\left.J_{\mathrm{H}-\mathrm{H}}=4.5 \mathrm{~Hz}, \operatorname{Ar} H\right) .{ }^{31} \mathrm{P}\left\{{ }^{1} \mathrm{H}\right\}$ $\operatorname{NMR}\left(\mathrm{CD}_{2} \mathrm{Cl}_{2}\right): \delta 72.5\left(\mathrm{dd}, J_{\mathrm{Rh}-\mathrm{P}}=182 \mathrm{~Hz}, J_{\mathrm{P}-\mathrm{P}}=40 \mathrm{~Hz}\right), 32.7\left(\mathrm{dd}, J_{\mathrm{Rh}-\mathrm{P}}=170 \mathrm{~Hz}, J_{\mathrm{P}-\mathrm{P}}=41 \mathrm{~Hz}\right)$. $\operatorname{ESIMS}(\mathrm{m} / z)$ for $\left[\mathrm{C}_{156} \mathrm{H}_{132} \mathrm{Cl}_{2} \mathrm{MgN}_{8} \mathrm{O}_{2} \mathrm{P}_{4} \mathrm{~S}_{2} \mathrm{Rh}_{2} \mathrm{Zn}\right]^{2+}$ : Calcd. 1352.6. Found: 1351.7.

(3)(4) $\mathbf{R h}_{2} \mathbf{C l}_{2}$ (Compound 6). Ligand 3 (96.2 mg, $\left.0.0789 \mathrm{mmol}\right)$, ligand 4 (100 mg, 0.0789 $\mathrm{mmol})$ and $[\mathrm{Rh}(\mathrm{COD}) \mathrm{Cl}]_{2}(38.9 \mathrm{mg}, 0.0789 \mathrm{mmol})$ were added to $20-\mathrm{mL}$ vial and dissolved in THF $(15 \mathrm{~mL})$. This solution was transferred to a $50-\mathrm{mL}$ Schlenk round-bottom flask and sonicated for $1 \mathrm{~h}$. During the course of the reaction, the solution went from clear pink solution to a cloudy pink solution, at which point the solvent was removed under vacuum. The purple solid was sonicated in hexanes $(20 \mathrm{~mL})$ for $1 \mathrm{~h}$, filtered, washed with fresh $\mathrm{Et}_{2} \mathrm{O}(2 \times 10 \mathrm{~mL})$ and dried under vacuum to yield 6 as an air-sensitive solid (201 mg, 93\% yield). ${ }^{1} \mathrm{H}$ NMR $\left(\mathrm{CD}_{2} \mathrm{Cl}_{2}\right)$ : $\delta$ 1.19 - 1.40 (br m, 24H, mesityl), 2.47 - 2.56 (br m, 12H, mesityl), 2.77 (m, 4H, $\mathrm{SCH}_{2} \mathrm{CH}_{2} \mathrm{P}$ ), $2.82\left(\mathrm{~m}, 4 \mathrm{H}, \mathrm{SCH}_{2} \mathrm{CH}_{2} \mathrm{P}\right), 3.08\left(\mathrm{~m}, 4 \mathrm{H}, \mathrm{OCH}_{2} \mathrm{CH}_{2} \mathrm{P}\right), 5.24$ (br m, 4H, $\mathrm{OCH}_{2} \mathrm{CH}_{2} \mathrm{P}$ ), $7.08-7.41$ (br m, 32H, ArH) $7.57-7.75$ (br m, 16H, ArH), 7.95 (d, 2H, $\left.J_{\mathrm{H}-\mathrm{H}}=7.8 \mathrm{~Hz}, \operatorname{ArH}\right), 8.13$ (d, 2H, $\left.J_{\mathrm{H}-\mathrm{H}}=8.4 \mathrm{~Hz}, \operatorname{Ar} H\right), 8.35(\mathrm{~m}, 6 \mathrm{H}, \operatorname{Ar} H), 8.56\left(\mathrm{~d}, 4 \mathrm{H}, J_{\mathrm{H}-\mathrm{H}}=4.2 \mathrm{~Hz}, \operatorname{Ar} H\right), 8.67\left(\mathrm{~d}, 2 \mathrm{H}, J_{\mathrm{H}-\mathrm{H}}=4.2\right.$ $\mathrm{Hz}, \operatorname{Ar} H), 8.89\left(\mathrm{~d}, 2 \mathrm{H}, J_{\mathrm{H}-\mathrm{H}}=6.0 \mathrm{~Hz}, \mathrm{Ar} H\right) .{ }^{31} \mathrm{P}\left\{{ }^{1} \mathrm{H}\right\} \mathrm{NMR}\left(\mathrm{CD}_{2} \mathrm{Cl}_{2}\right): \delta 72.5\left(\mathrm{dd}, J_{\mathrm{Rh}-\mathrm{P}}=182 \mathrm{~Hz}\right.$, $\left.J_{\mathrm{P}-\mathrm{P}}=40 \mathrm{~Hz}\right), 32.7\left(\mathrm{dd}, J_{\mathrm{Rh}-\mathrm{P}}=170 \mathrm{~Hz}, J_{\mathrm{P}-\mathrm{P}}=41 \mathrm{~Hz}\right) . \quad \operatorname{ESIMS}(m / z)$ for $\left[\mathrm{C}_{156} \mathrm{H}_{132} \mathrm{Cl}_{2} \mathrm{~N}_{8} \mathrm{O}_{2} \mathrm{P}_{4} \mathrm{~S}_{2} \mathrm{Rh}_{2} \mathrm{Zn}_{2}\right]^{2+}$ : Calcd. 1373.1. Found: 1373.3.

[(2)(4)Rh $\left.\mathbf{R h}_{2}\right]\left[\mathbf{B}(\mathbf{A r F})_{4}\right]_{2}$ (Compound 7). Compound $5(184.0 \mathrm{mg}, 0.0680 \mathrm{mmol})$ and $\mathrm{Na}\left[\mathrm{B}(\mathrm{ArF})_{4}\right](121.0 \mathrm{mg}, 0.136 \mathrm{mmol})$ were added to a $20-\mathrm{mL}$ vial and dissolved in $\mathrm{CH}_{2} \mathrm{Cl}_{2}(15$ $\mathrm{mL}$ ). The contents were sonicated for $1 \mathrm{~h}$ at which point the vial was cooled to $-30{ }^{\circ} \mathrm{C}$ for $1 \mathrm{~h}$, followed by filtration of the solution through a plug of Celite (to remove $\mathrm{NaCl}$ ) into a $25 \mathrm{~mL}$ Schlenk round-bottom flask. The solvent was removed under vacuum affording 7 as a air- 
sensitive purple microcrystalline solid (286 mg, 96\% yield). ${ }^{1} \mathrm{H}$ NMR $\left(\mathrm{CD}_{2} \mathrm{Cl}_{2}\right): \delta 1.59$ (br m, 24H, mesityl), 2.33 (br m, 12H, mesityl), 2.54 (4H, $\mathrm{SCH}_{2} \mathrm{CH}_{2} \mathrm{P}$ ), 2.76 (m, 2H, $\mathrm{SCH}_{2} \mathrm{CH}_{2} \mathrm{P}$ ), 2.93 (m, 2H, OCH $\left.\mathrm{OCH}_{2} \mathrm{P}\right), 4.43\left(\mathrm{~m}, 4 \mathrm{H}, \mathrm{OCH}_{2} \mathrm{CH}_{2} \mathrm{P}\right), 6.96-8.80(\mathrm{br} \mathrm{m}, 104 \mathrm{H}, \mathrm{Ar} H) .{ }^{31} \mathrm{P}\left\{{ }^{1} \mathrm{H}\right\} \mathrm{NMR}$ $\left(\mathrm{CD}_{2} \mathrm{Cl}_{2}\right): \delta 72.9\left(\mathrm{br} \mathrm{dd}, J_{\mathrm{Rh}-\mathrm{P}}=198 \mathrm{~Hz}, J_{\mathrm{P}-\mathrm{P}}=40 \mathrm{~Hz}\right), 51.4\left(\mathrm{dd}, J_{\mathrm{Rh}-\mathrm{P}}=167 \mathrm{~Hz}, J_{\mathrm{P}-\mathrm{P}}=41 \mathrm{~Hz}\right)$. $\operatorname{ESIMS~}(\mathrm{m} / z)$ for $\left[\mathrm{C}_{156} \mathrm{H}_{132} \mathrm{MgN}_{8} \mathrm{O}_{2} \mathrm{P}_{4} \mathrm{~S}_{2} \mathrm{Rh}_{2} \mathrm{Zn}\right]^{2+}$ : Calcd. 1317.1. Found: 1316.8 .

[(3)(4)Rh $\left.\mathbf{R h}_{2}\right]\left[\mathbf{B}(\mathrm{ArF})_{4}\right]_{2}$ (Compound 8). Compound $\mathbf{6}(185.0 \mathrm{mg}, 0.0674 \mathrm{mmol})$ and $\mathrm{Na}\left[\mathrm{B}(\mathrm{ArF})_{4}\right](120.0 \mathrm{mg}, 0.135 \mathrm{mmol})$ were added to a vial and dissolved in $\mathrm{CH}_{2} \mathrm{Cl}_{2}(15 \mathrm{~mL})$. The contents were sonicated for $1 \mathrm{~h}$ at which point the vial was cooled to $-30{ }^{\circ} \mathrm{C}$ for $1 \mathrm{~h}$, followed by filtration of the solution through a plug of Celite (to remove $\mathrm{NaCl}$ ) into a $25 \mathrm{~mL}$ Schlenk round-bottom flask. The solvent was removed under vacuum affording $\mathbf{8}$ as an airsensitive purple microcrystalline solid (283 mg, 94\% yield). ${ }^{1} \mathrm{H}$ NMR $\left(\mathrm{CD}_{2} \mathrm{Cl}_{2}\right): \delta 1.49$ (br m, 24H, mesityl), 2.28 (br m, 16H, mesityl and $\mathrm{SCH}_{2} \mathrm{CH}_{2} \mathrm{P}$ ), 2.76 (br m, 4H, $\mathrm{SCH}_{2} \mathrm{CH}_{2} \mathrm{P}$ ), 2.93 (br m, 4H, OCH $\mathrm{CH}_{2} \mathrm{P}$ ), 4.43 (br m, 4H, OCH $\mathrm{CH}_{2} \mathrm{P}$ ), $7.34-8.74$ (br m, 104H, $\operatorname{Ar} H$ ). ${ }^{31} \mathrm{P}\left\{{ }^{1} \mathrm{H}\right\}$ $\operatorname{NMR}\left(\mathrm{CD}_{2} \mathrm{Cl}_{2}\right): \delta 72.5\left(\mathrm{dd}, J_{\mathrm{Rh}-\mathrm{P}}=198 \mathrm{~Hz}, J_{\mathrm{P}-\mathrm{P}}=40 \mathrm{~Hz}\right), 51.6\left(\mathrm{dd}, J_{\mathrm{Rh}-\mathrm{P}}=167 \mathrm{~Hz}, J_{\mathrm{P}-\mathrm{P}}=41 \mathrm{~Hz}\right)$. ESIMS $(m / z)$ for $\left[\mathrm{C}_{156} \mathrm{H}_{132} \mathrm{~N}_{8} \mathrm{O}_{2} \mathrm{P}_{4} \mathrm{~S}_{2} \mathrm{Rh}_{2} \mathrm{Zn}_{2}\right]^{2+}$ : Calcd. 1337.6. Found: 1337.7.

$\left[(2)(4) \mathrm{Rh}_{2}(\mathrm{CO})_{2}\right][\mathrm{BArF}]_{2}$ (Compound 9). Compound 9 can be prepared according to two separate methods. Method A: In a glove box, compound 7 (10.0 $\mathrm{mg}, 0.00229 \mathrm{mmol})$ was added to a 5-mL vial, dissolved in $\mathrm{CD}_{2} \mathrm{Cl}_{2}(1 \mathrm{~mL})$ and was transferred to a $10-\mathrm{mL}$ Schlenk flask. The flask was placed on a Schlenk line where the $\mathrm{N}_{2}$ atmosphere in the flask was evacuated and replaced with an atmosphere of $\mathrm{CO}(1 \mathrm{~atm})$. The contents were sonicated for $30 \mathrm{~s}$ at which point the flask was brought into a glove box and the solution was transferred to an air-free NMR tube. The yield of 9 was determined to be quantitative as indicated by ${ }^{31} \mathrm{P}\left\{{ }^{1} \mathrm{H}\right\}$ NMR spectroscopy. Method B: In a glove box, compound $5(10.0 \mathrm{mg}, 0.00364 \mathrm{mmol})$ was added to a 5 - $\mathrm{mL}$ vial, dissolved in $\mathrm{CD}_{2} \mathrm{Cl}_{2}(1 \mathrm{~mL})$ and transferred to a $10-\mathrm{mL}$ Schlenk flask. The Schlenk flask was placed on a Schlenk line where the $\mathrm{N}_{2}$ atmosphere in the flask was evacuated and replaced with an atmosphere of CO (1 atm), resulting in the in situ generation of compound 11. The flask was brought back into the glove box where $\mathrm{Na}\left[\mathrm{B}(\mathrm{ArF})_{4}\right](6.45 \mathrm{mg}, 0.00728 \mathrm{mmol})$ was added to the solution, at which point the solution was transferred to an air-free J-Young NMR tube. The resulting mixture was sonicated for $30 \mathrm{~min}$, which provided compound 9 in quantitative yield as 
was indicated by ${ }^{31} \mathrm{P}\left\{{ }^{1} \mathrm{H}\right\}$ NMR spectroscopy. ${ }^{1} \mathrm{H}$ NMR $\left(\mathrm{CD}_{2} \mathrm{Cl}_{2}\right): \delta 1.76$ (br s, 24H, mesityl), 2.57 (br s, 12H, mesityl), 3.03 (br m, 4H, $\mathrm{SCH}_{2} \mathrm{CH}_{2} \mathrm{P}$ ), 3.31 (br m, 8H, $\mathrm{SCH}_{2} \mathrm{CH}_{2} \mathrm{P}$ and $\mathrm{OCH}_{2} \mathrm{CH}_{2} \mathrm{P}$ ), 4.74 (br m, 4H, $\mathrm{OCH}_{2} \mathrm{CH}_{2} \mathrm{P}$ ), 7.15 - 8.13 (br m, 88H, $\mathrm{ArH}$ ), 8.74 (br m, 16H, $\mathrm{ArH}$ ). ${ }^{31} \mathrm{P}\left\{{ }^{1} \mathrm{H}\right\}$ NMR $\left(\mathrm{CD}_{2} \mathrm{Cl}_{2}\right): \delta 61.3\left(\mathrm{dd}, J_{\mathrm{Rh}-\mathrm{P}}=265 \mathrm{~Hz}, J_{\mathrm{P}-\mathrm{P}}=114 \mathrm{~Hz}\right), 18.6\left(\mathrm{dd}, J_{\mathrm{Rh}-\mathrm{P}}=263 \mathrm{~Hz}, J_{\mathrm{P}-}\right.$ $\mathrm{P}=115 \mathrm{~Hz})$. ESIMS $(\mathrm{m} / \mathrm{z})$ for $\left[\mathrm{C}_{158} \mathrm{H}_{132} \mathrm{MgN}_{8} \mathrm{O}_{4} \mathrm{P}_{4} \mathrm{~S}_{2} \mathrm{Rh}_{2} \mathrm{Zn}\right]^{2+}:$ Calcd. 1345.1. Found: 1346.3. FTIR: $v_{\mathrm{CO}}=1970 \mathrm{~cm}^{-1}$.

$\left[(3)(4) R_{2}(C O)_{2}\right][B A r F]_{2}$ (Compound 10). Compound 10 can be prepared according to two separate methods. Method A: Compound 8 (10.0 mg, $0.00227 \mathrm{mmol})$ was added to a 5-mL vial, dissolved in $\mathrm{CD}_{2} \mathrm{Cl}_{2}(1 \mathrm{~mL})$ and was transferred to a $10-\mathrm{mL}$ Schlenk flask. The flask was placed on a Schlenk line where the $\mathrm{N}_{2}$ atmosphere in the flask was evacuated and replaced with an atmosphere of CO (1 atm). The contents were sonicated for $30 \mathrm{~s}$ at which point the flask was brought into a glove box and the solution was transferred to an air-free NMR tube. The yield of 10 was determined to be quantitative as indicated by ${ }^{31} \mathrm{P}\left\{{ }^{1} \mathrm{H}\right\}$ NMR spectroscopy.

Method B: In a glove box, compound $6(10.0 \mathrm{mg}, 0.00370 \mathrm{mmol})$ was added to a 5-mL vial, dissolved in $\mathrm{CD}_{2} \mathrm{Cl}_{2}(1 \mathrm{~mL})$ and transferred to a $10-\mathrm{mL}$ Schlenk flask. The Schlenk flask was placed on a Schlenk line where the $\mathrm{N}_{2}$ atmosphere in the flask was evacuated and replaced with an atmosphere of CO (1 atm), resulting in the in situ generation of compound 12. The flask was brought back into the glove box where $\mathrm{Na}\left[\mathrm{B}(\mathrm{ArF})_{4}\right](6.55 \mathrm{mg}, 0.00740 \mathrm{mmol})$ was added to the solution, at which point the solution was transferred to an air-free J-Young NMR tube. The resulting mixture was sonicated for $30 \mathrm{~min}$, which provided compound $\mathbf{1 0}$ in quantitative yield as was indicated by ${ }^{31} \mathrm{P}\left\{{ }^{1} \mathrm{H}\right\} \mathrm{NMR}$ spectroscopy. $\quad{ }^{1} \mathrm{H} \mathrm{NMR}\left(\mathrm{CD}_{2} \mathrm{Cl}_{2}\right): \delta 1.76$ (br s, 24H, mesityl), 2.57 (br s, 12H, mesityl), 3.03 (br m, 4H, $\mathrm{SCH}_{2} \mathrm{CH}_{2} \mathrm{P}$ ), 3.31 (br m, 8H, $\mathrm{SCH}_{2} \mathrm{CH}_{2} \mathrm{P}$ and $\mathrm{OCH}_{2} \mathrm{CH}_{2} \mathrm{P}$ ), 4.74 (br m, 4H, $\mathrm{OCH}_{2} \mathrm{CH}_{2} \mathrm{P}$ ), 7.15 - 8.13 (br m, 88H, $\mathrm{ArH}$ ), 8.74 (bm, 16H, $\mathrm{ArH}$ ). ${ }^{31} \mathrm{P}\left\{{ }^{1} \mathrm{H}\right\} \mathrm{NMR}\left(\mathrm{CD}_{2} \mathrm{Cl}_{2}\right): \delta 61.3\left(\mathrm{dd}, J_{\mathrm{Rh}-\mathrm{P}}=265 \mathrm{~Hz}, J_{\mathrm{P}-\mathrm{P}}=114 \mathrm{~Hz}\right), 18.6\left(\mathrm{dd}, J_{\mathrm{Rh}-\mathrm{P}}=263 \mathrm{~Hz}, J_{\mathrm{P}-}\right.$ $\mathrm{P}=115 \mathrm{~Hz})$. ESIMS $(\mathrm{m} / z)$ for $\left[\mathrm{C}_{158} \mathrm{H}_{132} \mathrm{~N}_{8} \mathrm{O}_{4} \mathrm{P}_{4} \mathrm{~S}_{2} \mathrm{Rh}_{2} \mathrm{Zn}_{2}\right]^{2+}:$ Calcd. 1365.7. Found: 1365.3. FTIR: $v_{\mathrm{CO}}=1970 \mathrm{~cm}^{-1}$.

(2)(4) $\mathrm{Rh}_{2} \mathrm{Cl}_{2}(\mathrm{CO})_{2}$ (Compound 11). Compound 11 can be prepared according to two separate methods. Since Method A relies only on the addition of CO (1 atm) to the sample, the product from this reaction was used for all of the necessary characterization. Method A: Compound 5 
(10.0 mg, $0.00364 \mathrm{mmol})$ was weighed out into a 5-mL vial, suspended in $\mathrm{CD}_{2} \mathrm{Cl}_{2}(1 \mathrm{~mL})$ and transferred to a $10-\mathrm{mL}$ Schlenk flask. The flask was placed on a Schlenk line where the $\mathrm{N}_{2}$ atmosphere was removed and replaced with CO (1 atm). The flask was sonicated for $30 \mathrm{~s}$ and brought into a glove box where the solution was transferred to an air-free J-Young NMR tube. Analysis of this solution by ${ }^{1} \mathrm{H}$ NMR and ${ }^{31} \mathrm{P}\left\{{ }^{1} \mathrm{H}\right\}$ NMR spectroscopy indicated the quantitative conversion of 5 to $\mathbf{1 1}$.

Method B: Compound $7(10.0 \mathrm{mg}, 0.00228 \mathrm{mmol})$ and $(n-\mathrm{Bu})_{4} \mathrm{NCl}(1.26 \mathrm{mg}, 0.00456 \mathrm{mmol})$ were weighed out into a 5-mL vial, suspended in $\mathrm{CD}_{2} \mathrm{Cl}_{2}(1 \mathrm{~mL})$ and transferred to a $10-\mathrm{mL}$ Schlenk flask. The flask was placed on a Schlenk line where the $\mathrm{N}_{2}$ atmosphere was removed and replaced with CO (1 atm). The flask was sonicated for $30 \mathrm{~s}$ and brought into a glove box where the solution was transferred to an air-free J-Young NMR tube. Analysis of this solution by ${ }^{1} \mathrm{H}$ NMR and ${ }^{31} \mathrm{P}\left\{{ }^{1} \mathrm{H}\right\}$ NMR indicated the quantitative conversion of 7 to $11 .{ }^{1} \mathrm{H}$ NMR $\left(\mathrm{CD}_{2} \mathrm{Cl}_{2}\right.$ ): $\delta 1.69$ (br m, 24H, mesityl), 2.46 (br m, 12H, mesityl), 3.12 (br m, 4H, $\mathrm{SCH}_{2} \mathrm{CH}_{2} \mathrm{P}$ ), 3.31 (br m, 4H, $\mathrm{SCH}_{2} \mathrm{CH}_{2} \mathrm{P}$ ), 3.48 (br m, 4H, $\mathrm{OCH}_{2} \mathrm{CH}_{2} \mathrm{P}$ ), 4.77 (br m, 4H, $\mathrm{OCH}_{2} \mathrm{CH}_{2} \mathrm{P}$ ), 7.13 (br m, 16H, ArH), 7.43 (br s, 24H, ArH), 7.81 - 7.98 (br m, 24H, ArH), 8.55 (br d, 8H, ArH), 8.75 (br d, $8 \mathrm{H}, \quad \mathrm{Ar} H) . \quad{ }^{31} \mathrm{P}\left\{{ }^{1} \mathrm{H}\right\} \quad \mathrm{NMR} \quad\left(\mathrm{CD}_{2} \mathrm{Cl}_{2}\right): \quad \delta \sim 23 \quad($ br $\mathrm{m}) . \operatorname{ESIMS}(\mathrm{m} / z)$ for $\left[\mathrm{C}_{158} \mathrm{H}_{132} \mathrm{Cl}_{2} \mathrm{MgN}_{8} \mathrm{O}_{4} \mathrm{P}_{4} \mathrm{~S}_{2} \mathrm{Rh}_{2} \mathrm{Zn}\right]^{2+}\left(\mathrm{M}-2 \mathrm{Cl}^{-}\right)$: Calcd. 1345.1. Found: 1345.5. FTIR: $v_{\mathrm{CO}}=$ $1968 \mathrm{~cm}^{-1}$.

(3)(4) $\mathrm{Rh}_{2} \mathrm{Cl}_{2}(\mathrm{CO})_{2}$ (Compound 12). Compound 12 can be prepared according to two separate methods. Since Method A only relies on the addition of CO (1 atm) to the sample, the product from this reaction was used for the necessary characterization. Method A: Compound 6 (10.0 $\mathrm{mg}, 0.00364 \mathrm{mmol})$ was weighed out into a $5-\mathrm{mL}$ vial, suspended in $\mathrm{CD}_{2} \mathrm{Cl}_{2}(1 \mathrm{~mL})$ and transferred to a $10-\mathrm{mL}$ Schlenk flask. The flask was placed on a Schlenk line where the $\mathrm{N}_{2}$ atmosphere was removed and replaced with $\mathrm{CO}(1 \mathrm{~atm})$. The flask was sonicated for $30 \mathrm{~s}$ and the flask was brought into a glove box where the solution was transferred to an air-free NMR tube. Analysis of this solution by ${ }^{1} \mathrm{H}$ NMR and ${ }^{31} \mathrm{P}\left\{{ }^{1} \mathrm{H}\right\}$ NMR spectroscopy indicated the quantitative conversion of $\mathbf{6}$ to $\mathbf{1 2 .}$

Method B: Compound $8(10.0 \mathrm{mg}, 0.00228 \mathrm{mmol})$ and $(n-\mathrm{Bu})_{4} \mathrm{NCl}(1.26 \mathrm{mg}, 0.00456 \mathrm{mmol})$ were weighed out into a 5-mL vial, suspended in $\mathrm{CD}_{2} \mathrm{Cl}_{2}(1 \mathrm{~mL})$ and transferred to a $10-\mathrm{mL}$ Schlenk flask. The flask was placed on a Schlenk line where the $\mathrm{N}_{2}$ atmosphere was removed 
and replaced with CO (1 atm). The flask was sonicated for $30 \mathrm{~s}$ and brought into a glove box where the solution was transferred to an air-free J-Young NMR tube. Analysis of this solution by ${ }^{1} \mathrm{H}$ NMR and ${ }^{31} \mathrm{P}\left\{{ }^{1} \mathrm{H}\right\}$ NMR spectroscopy indicated the quantitative conversion of 8 to $12 .{ }^{1} \mathrm{H}$ NMR $\left(\mathrm{CD}_{2} \mathrm{Cl}_{2}\right): \delta 1.78$ (br d, 24H, mesityl), 2.57 (br d, 12H, mesityl), 3.04 (br m, 4H, $\mathrm{SCH}_{2} \mathrm{CH}_{2} \mathrm{P}$ ), 3.37 (br m, 8H, $\mathrm{SCH}_{2} \mathrm{CH}_{2} \mathrm{P}$ and $\mathrm{OCH}_{2} \mathrm{CH}_{2} \mathrm{P}$ ), 4.75 (br m, 4H, $\mathrm{OCH}_{2} \mathrm{CH}_{2} \mathrm{P}$ ), 7.157.45 (br m, 36H, ArH), 7.83 (br m, 28H, ArH), 8.27 (br d, 8H, ArH), 8.81 (br d, 8H, ArH). ${ }^{31} \mathrm{P}\left\{{ }^{1} \mathrm{H}\right\} \operatorname{NMR}\left(\mathrm{CD}_{2} \mathrm{Cl}_{2}\right): \delta \sim 23$ (br m). ESIMS $(\mathrm{m} / z)$ for $\left[\mathrm{C}_{158} \mathrm{H}_{132} \mathrm{Cl}_{2} \mathrm{~N}_{8} \mathrm{O}_{4} \mathrm{P}_{4} \mathrm{~S}_{2} \mathrm{Rh}_{2} \mathrm{Zn}_{2}\right]^{2+}(\mathrm{M}-2$ $\left.\mathrm{Cl}^{-}\right)$: Calcd. 1365.7. Found: 1365.8. FTIR: $v_{\mathrm{CO}}=1965 \mathrm{~cm}^{-1}$.

\section{References}

1. Pangborn, A. B.; Giardello, M. A.; Grubbs, R. H.; Rosen, R. K.; Timmers, F. J. Organometallics. 1996, 15, 1518-20.

2. Oliveri, C. G.; Gianneschi, N. C.; Nguyen, S. T.; Mirkin, C. A.; Stern, C. L.; Wawrzak, Z.; Pink, M. J. Am. Chem. Soc. 2006, 128, 16286-16296. 